Article

\title{
The Biomass Potential and GHG (Greenhouse Gas) Emissions Mitigation of Straw-Based Biomass Power Plant: A Case Study in Anhui Province, China
}

\author{
Hui Li ${ }^{1, *}{ }^{\dagger}$, Xue Min ${ }^{1,+}$, Mingwei Dai ${ }^{1}$ and Xinju Dong ${ }^{2}$ \\ 1 School of Resources and Environment, Anhui Agricultural University, Hefei 230026, China \\ 2 Department of Chemistry, University of Louisville, Louisville, KT 40292, USA \\ * Correspondence: leehui@ahau.edu.cn \\ + These authors contribute equally to this work.
}

Received: 26 August 2019; Accepted: 3 September 2019; Published: 9 September 2019

check for updates

\begin{abstract}
Anhui Province (AHP), a typical agriculture-based province in China, has a significant amount of biomass resources for the development of biomass power plants. By the end of 2016, 23 straw based biomass power plants were established in AHP, aggregating to $6560 \mathrm{MW}$ capacity, which is now ranked second in China. This paper presents the current development status and GHG (Greenhouse Gas) mitigation effect of the straw based biomass power plants in Anhui Province. Total biomass production in 2016 was calculated as 41.84 million tons. Although there is huge biomass potential in AHP, the distribution is heterogeneous with a gradually decreasing trend from north to south. Furthermore, the installed capacity of power generation is also unmatched with the biomass resources. Based on a calculation made in 2016, approximately 3.44 million tons of $\mathrm{CO}_{2}$-eq were mitigated from the biomass power plants in AHP. The large-scale development of biomass power plants remains a challenge for the future, especially in areas of AHP with a low biomass density.
\end{abstract}

Keywords: biomass resource; power plant; GHG emission mitigation; Anhui

\section{Introduction}

Global energy demand was 14,050 Mtoe (million tons of oil equivalent) in 2017, with a growth rate of $2.1 \%$, and global energy-related $\mathrm{CO}_{2}$ emissions increased by $1.4 \%$, reaching a historically high value of 32.5 GT [1]. China has a large population and rapid growth of the population, industrialization, and urbanization, and the energy consumption has sharply increased, up to 3053 Mtoe in 2017, of which more than $70 \%$ of energy consumption was supported by coal [2,3]. Due to this coal-dominated energy consumption, greenhouse gas (GHG) and particulate matter (PM) pollutants are released during the coal utilization process, leading to a negative impact on health and the environment in China and globally [4-9]. Therefore, preferential concern and policies for clean energy associated with the "Energy Revolution" and "Fight Against Pollution" in China have received an intense level of support [10].

Presently, biomass energy plays a significant role in energy production, and is listed as the fourth largest energy source worldwide after oil, coal and natural gas [11,12]. With carbon-neutral, clean and sustainable characteristics [13-15], biomass has been proven to be promising renewable energy in China with a theoretical maximum potential energy of 18,833 PJ in 2030 [16]. To utilize biomass energy, current technologies including combustion, liquefaction, pyrolysis/gasification, digestion, and fermentation have been widely used in developing countries $[17,18]$. Among various technologies, biomass power generation is a high-efficiency approach for biomass utilization that has been promoted and developed for sustainable energy output, and that also offers a flexible approach for straw disposal $[19,20]$. By the end of 2011, the global installed capacity of biomass plants was $72 \mathrm{GW}$ with total electricity generation 
of 265-529 TWh [21]. The installed capacity of biomass power generation in China has gradually increased, as showed in Figure 1, a total value of 18,790 MW in 2016, most of these plants are fueled by agricultural residues and forest products. The growth rate decreased from 2013 to 2016, indicating that the large-scale development of biomass power plants is accompanied by some problems, including the biomass supply capacity, fuel cost, and environmental impacts [2,22-24]. The environmental impacts of biomass power plants mainly include landfill, water and ash treatment [25-27]. Zhao and Li [28] performed a numerical example analysis of biomass power plant and noted that pollutant emissions during straw transportation were neglected. Research on the physical, mental and social impacts of small-scale biomass power plants indicated that air pollutant was the main concern of local people [29]. Zhang et al. [30] indicated that the cost of a straw-based power plant is indeed high, most of which was the fuel cost. Nguyen et al. found that the environmental performance of straw power plants was worse than that of natural gas [31]. In addition, although some studies have emphasized the potential for negative net GHG emissions from biomass power plants, the recognition of GHGs mitigation is not fully understood [10]. Therefore, some studies have indicated that the development of biomass power plants should be more steady in China [32,33].

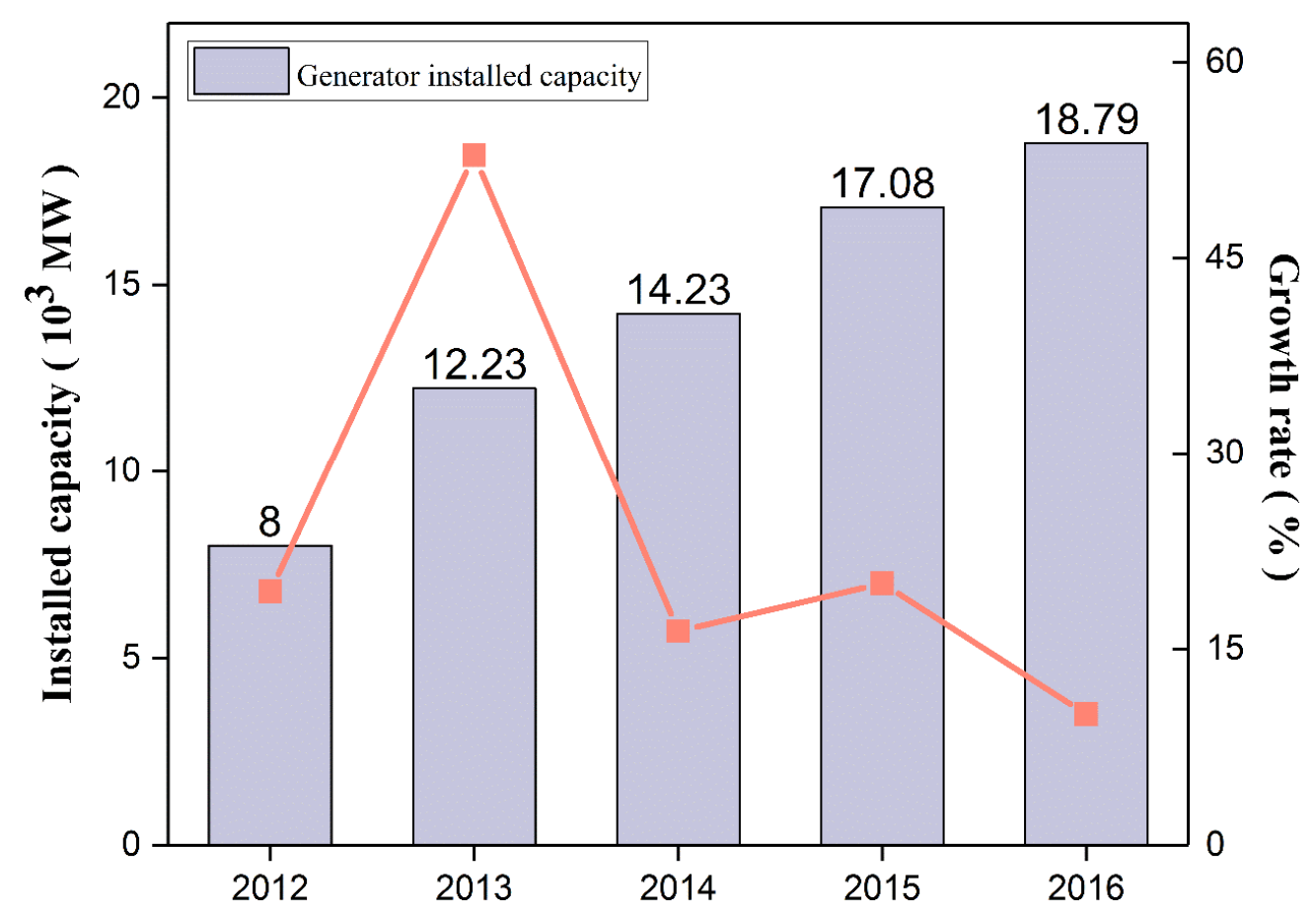

Figure 1. Installed capacity of biomass power generation in China from 2012 to 2016. Note: The original data were obtained from the database of National Renewable Energy Information management Centre in China.

Anhui Province (AHP), see in Figure 2, located in eastern China (N29 $41^{\prime}-\mathrm{N} 34^{\circ} 38^{\prime}$, E114 $\left.{ }^{\circ} 54^{\prime}-\mathrm{E} 119^{\circ} 37^{\prime}\right)$, is a typical agricultural Province, with a huge amount of biomass resources, such as forest and agricultural residues [34]. The government of Anhui province has been strongly encouraging and supporting the construction and development of biomass power generation plants. "The research report of the "13th Five-Year Plan" for Straw Power Generation in Anhui Province" published by the Anhui government proposed installed capacity of approximately 1600 MW by the end of 2020. According to the statistical data from the Anhui Energy Administration, a total of 23 grid-connected straw-based biomass power plants with an installed capacity of $660 \mathrm{MW}$ were built and operational from 2006. Even with policy support, the development of biomass power plants still needs a systematic study on feedstock analysis and environmental impact assessment. Therefore, in this study, we investigated the current status and GHG emissions from straw-based power plants in 
Anhui Province. First, the development, operation, and profitability of power plants were discussed in detail. In addition, the production, distribution, and availability of biomass resources in AHP were examined. Finally, the potential mitigation of greenhouse gas emissions attributed to straw-based power plants was calculated. The results can provide valuable information to policymakers and will be useful for the development of straw-based power plants in China.

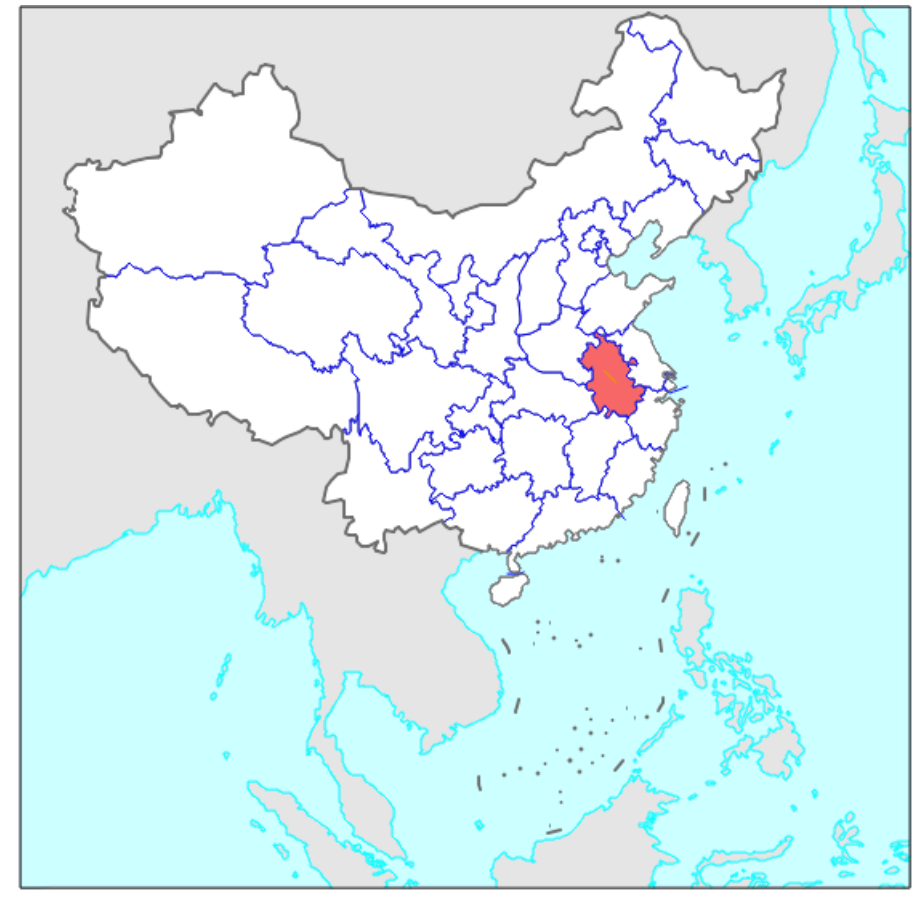

Figure 2. Location of Anhui province in China.

\section{Materials and Methods}

With the aim of producing comprehensive information about the biomass resources, operational condition and mitigation of GHGs associated with biomass power plants in AHP, data were obtained from official and provincial reports, yearbooks, online reports, and other sources. Data and information about biomass resources were obtained from the Anhui statistical yearbook (2012-2016), agricultural mechanization statistics report for Anhui (2012-2016) and the national agricultural mechanization information website (Appendix A.1). Data and information related to the operational condition of biomass power plant were obtained from the Anhui Energy Bureau. The methods used to calculate the biomass potential and GHG mitigation were the crop-to-residue index and the CM-092-V01 method, respectively (see Appendix A for further details).

\section{Results and Discussion}

\subsection{Biomass Production and Characterization}

Biomass resource potential is an important challenge for the development of biomass power plants. AHP has a huge amount of biomass resources from agriculture and forestry. The total land area is $139,427 \mathrm{~km}^{2}$, of which $58,730 \mathrm{~km}^{2}$ is cultivated land and $39,585 \mathrm{~km}^{2}$ is forest land [35]. Production of crop straw is evaluated based on the crop-to-residue index (CRI) value, namely 1.38 for wheat straw, 2.05 for corn straw, 1.26 for rice straw, 1.68 for bean straw, and 1.16 for potato straw [36].

Biomass availability in AHP varied in term of spatial and temporal distribution. Figure 3 shows the availability of total biomass production from 2012 to 2016 . The total yield increased slowly from 36.25 to 41.84 million tons, with the highest value of 43.20 million tons in 2015 . The forestry byproducts gradually increased at a rate of $23.15 \%$ due to the increase in forest area supported by the local 
government. The crop straw yield was raised to 36.41 million tons in 2016, with an increased rate of $4.52 \%$. Our previous research indicated that the total crop production and harvesting approach are the two main factors that impact straw production, and with the rapid development of mechanized harvesting, less straw is collected for utilization [36].

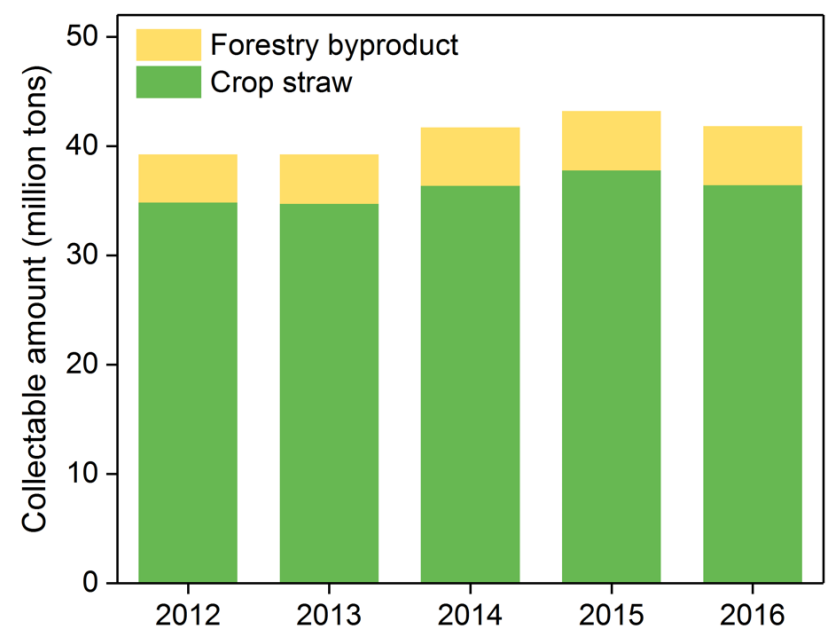

Figure 3. The total collectable amount of biomass resource in Anhui Province (AHP) from 2012 to 2016.

Abbreviation of cities: SZ for Suzhou city, BZ for Bozhou city, FY for Fuyang city, BB for Bengbu city, HN for Huainan city, XC for Xuancheng city, HB for Huaibei city, HF for Hefei city, LA for Lu'an city, Cuz for Chuzhou city, MAS for Ma'anshan city, WH for Wuhu city, TL for Tonglin city, CiZ for Chizhou city, AQ for Anqing city, HS for Huangshan city.

Geographically, biomass availability is spatially nonuniform in AHP and is disproportionately concentrated in the northern part of AHP as showed in Figure 4, because of the different land availability and productivity. The total biomass production was mainly concentrated in the northern part of AHP, with a proportion of $56 \%$, compared with $22.3 \%$ and $21.7 \%$ in central and southern AHP, respectively. With respect to forestry byproducts, approximately $63.57 \%$ of the resources were generated from the southern part of AHP, such as Xuancheng, Chizhou, Huangshan cities. In addition, the distribution of the biomass power plants is not consistent with that of straw resources, except for Huangshan and Tongling cities, which have no power plant due to their low biomass availability. However, installed capacity of Lu'an city was the highest among all the cities, although the biomass availability is low.

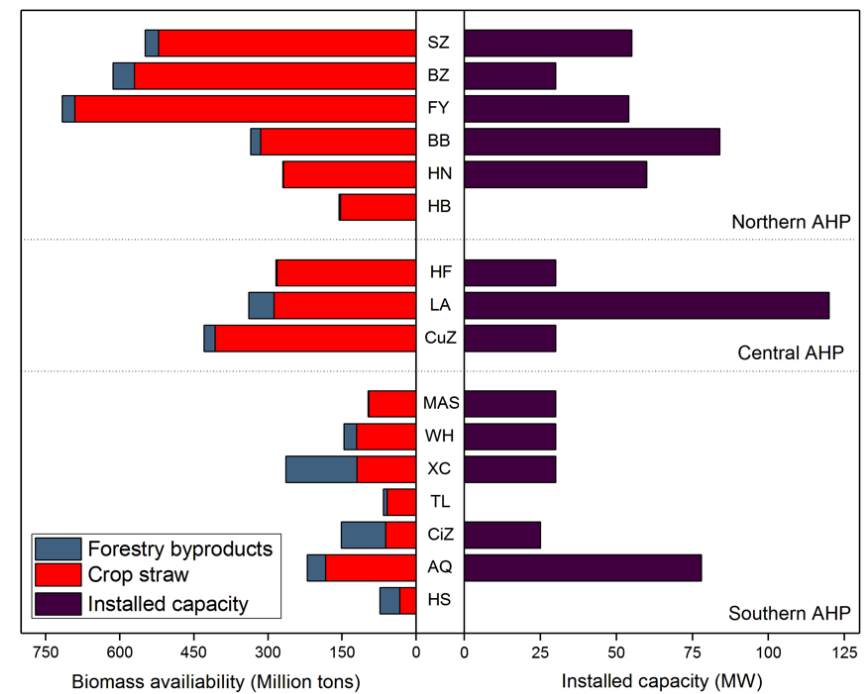

Figure 4. The biomass availability and installed capacity of biomass power plant in AHP, 2016. 


\subsection{Assessment and Availability Analysis}

The high production of biomass in AHP provides opportunities for the development of biomass power plants. The Chinese official legislation promulgated in 2006 restricted the outdoor burning of straw, and approximately $23.7 \%$ of straw is used for fuel. Biomass availability is dependent largely on location and climate. To better describe the distribution of biomass, it is common to select the biomass density, which is defined as the ratio of the collectable biomass production to the total land area [37]. It is concluded from previous studies that a low biomass density will result in high collection, delivery and storage costs. As showed in Figure 5, the density of biomass resources for each city was calculated. It should be noted that the geographical straw density differed considerably from 75.40 to $733.30 \mathrm{t} / \mathrm{km}^{2}$, with a mean value of $361.77 \mathrm{t} / \mathrm{km}^{2}$. However, the biomass density decreases gradually from north to south in AHP which is consistent with the results found in other literature [36]. Bozhou and Fuyang have high densities, more than $700 \mathrm{t} / \mathrm{km}^{2}$, and the densities of central and southern AHP (Hefei, Wuhu, Maanshan, Lu'an, Tongling, Xuancheng, Chizhou, Anqing, and Huangshan) are relatively low, less than $300 \mathrm{t} / \mathrm{km}^{2}$, and the lowest value is observed in the southern area.

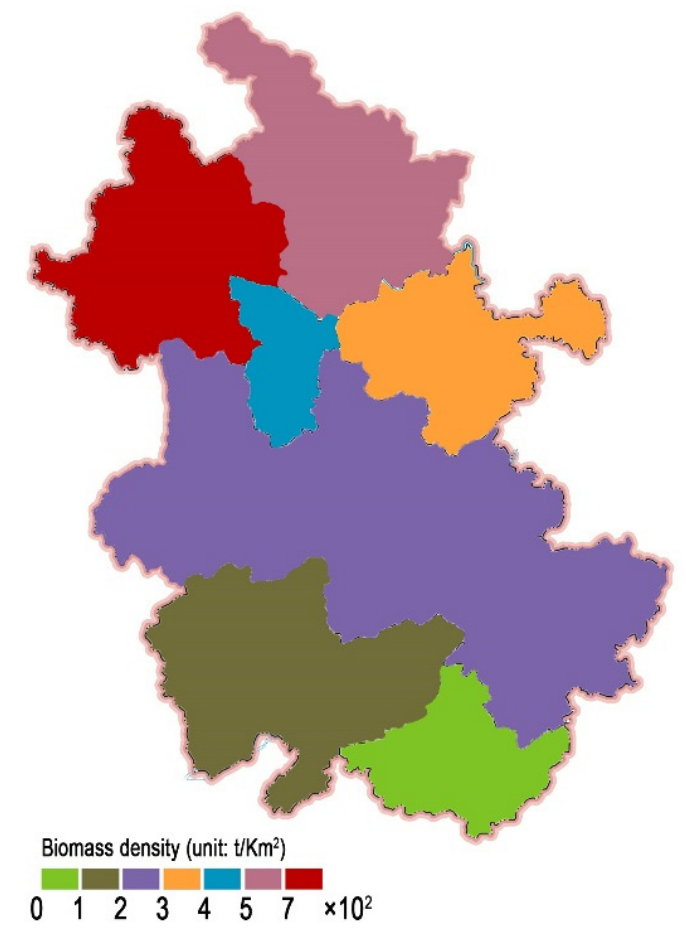

Figure 5. The biomass density in AHP (unit: $\mathrm{t} / \mathrm{Km}^{2}$ ).

With low-density energy resource, the distribution and sustainable supply of biomass feedstock have a great influence on the collection and storage cost [38]. It is recommended that the economical collection radius should be less than $50 \mathrm{~km}$ for profitability [30]. In addition, only $20 \%$ of the available biomass is used for power plants in general due to their alternative utilization activities. Therefore, the net theoretical available potential (NAP, within a $50 \mathrm{~km}$ radius with a supply assurance factor of 0.3 ) amount of biomass for power generation was calculated in this study. The biomass consumption was approximately $0.17-0.29$ million tons for a $30 \mathrm{MW}$ biomass power plant based on the calorific values [39]. As shown in Figure 6, within $50 \mathrm{~km}$, the biomass from northern AHP can completely fuel the demand of a power plant, while the central and southern AHP exhibited a lower NAP, making it difficult to meet the feedstock demand. Most biomass power plants have a relatively low capacity for biomass collection, leading to the final price of biomass reaching more than approximately 50 USD per ton, which is economically unacceptable. 


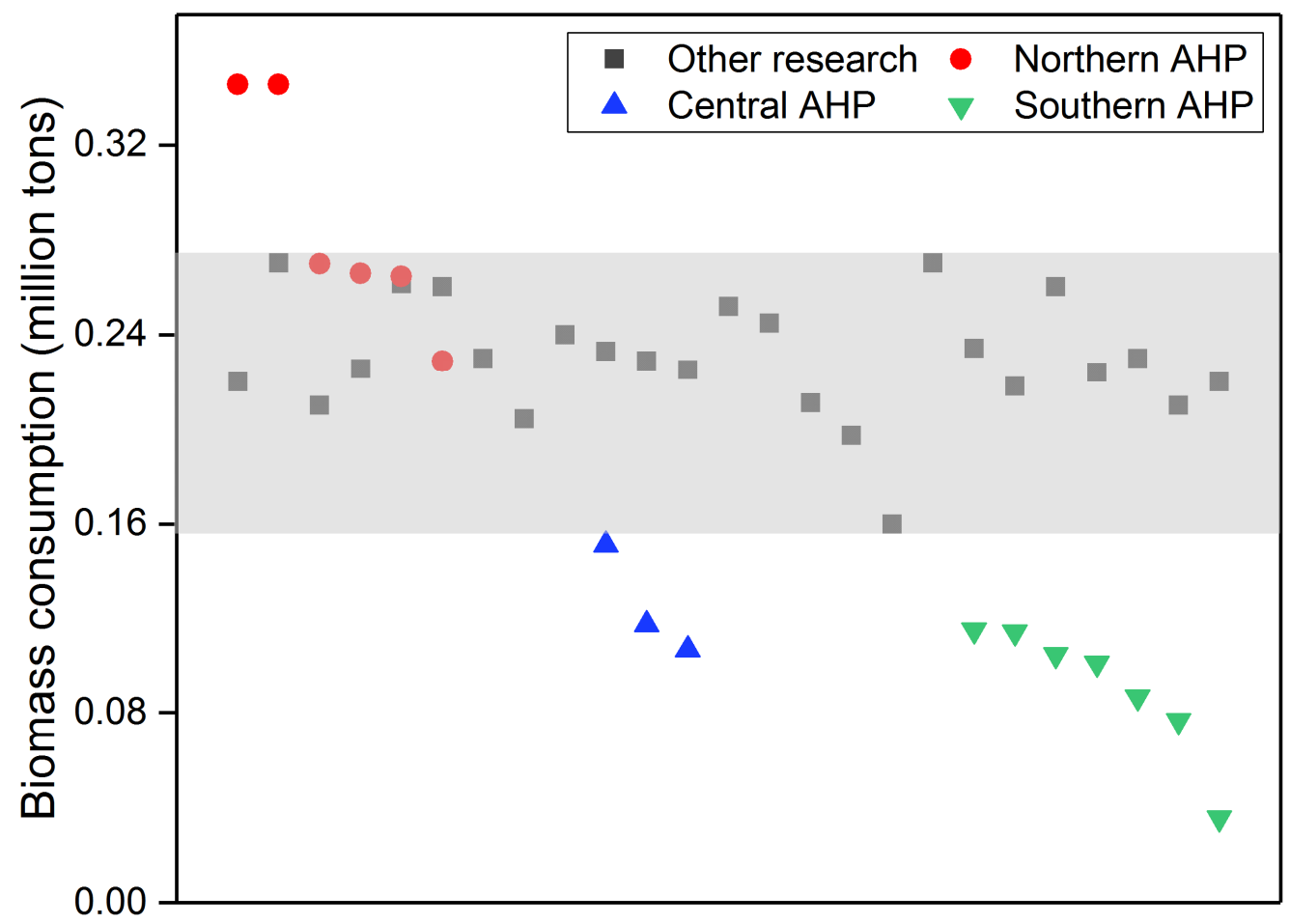

Figure 6. The maximum net theoretical available potential (NAP) of biomass in each city from AHP (with the supply assurance factor of 0.3 ).

\subsection{General Status of Biomass-Based Power Generation}

The first $2 \times 15$ MW biomass-based power plant in AHP was established in 2006, with a total investment of 280 million RMB by the Datang Power Group in Anqing City. According to statistics, this project consumes 235,000 tons of biomass and generates more than $190 \mathrm{GWh}$ of electricity per year. A total of 20 grid-connected biomass power plants with a power capacity of $6560 \mathrm{MW}$ have been installed by the end of 2016 such that AHP possess the second largest biomass capacity in China. The power plants in AHP are in the range of 24-30 MW with an average scale of $28.5 \mathrm{MW}$, which is much smaller than that of coal-fired power plants. A total of $73.9 \%$ of the plants are designed for 30 MW due to the limit of fuel sources, capital and operational costs, and other factors [40].

According to the statistical data from the Anhui Energy Bureau, the total power generation of 20 biomass power plants in 2016 was 377.1 billion KWh, with a total operation of 132,980 h in 2016. As shown in Figure 7, the annual utilization hours of the 20 straw-based power plants varied greatly from 3275 to $8184 \mathrm{~h}$, with a mean value of $6649 \mathrm{~h}$. Nearly half of the plants operated for more than $6000 \mathrm{~h}$ per year. The power generation varied between the 20 plants, the highest was 244.45 million KWh in Suzhou City, and the lowest was 98.27 million KWh in Lu'an City.

Compared with fossil energy, there is generally no economically competitive biomass energy due to its high capital, operating and maintenance costs [41,42]. The investment cost of biomass power plants is relatively higher than that of thermal power and hydropower plants, even though the cost has decreased in recent years. Based on the estimation by Zhang et al. [32], the average unit cost is approximated $9900 \mathrm{RMB} / \mathrm{kW}$ or $0.738 \mathrm{RMB} / \mathrm{KWh}$, more than double of that of a thermal power plant [43]. In addition, the high cost of handling and shipping is still challenging for some biomass power plants in AHP, especially with the shortage of rural manpower [38]. The biomass purchased price should be less than $220 \mathrm{RMB} /$ ton to provide a benefit. 


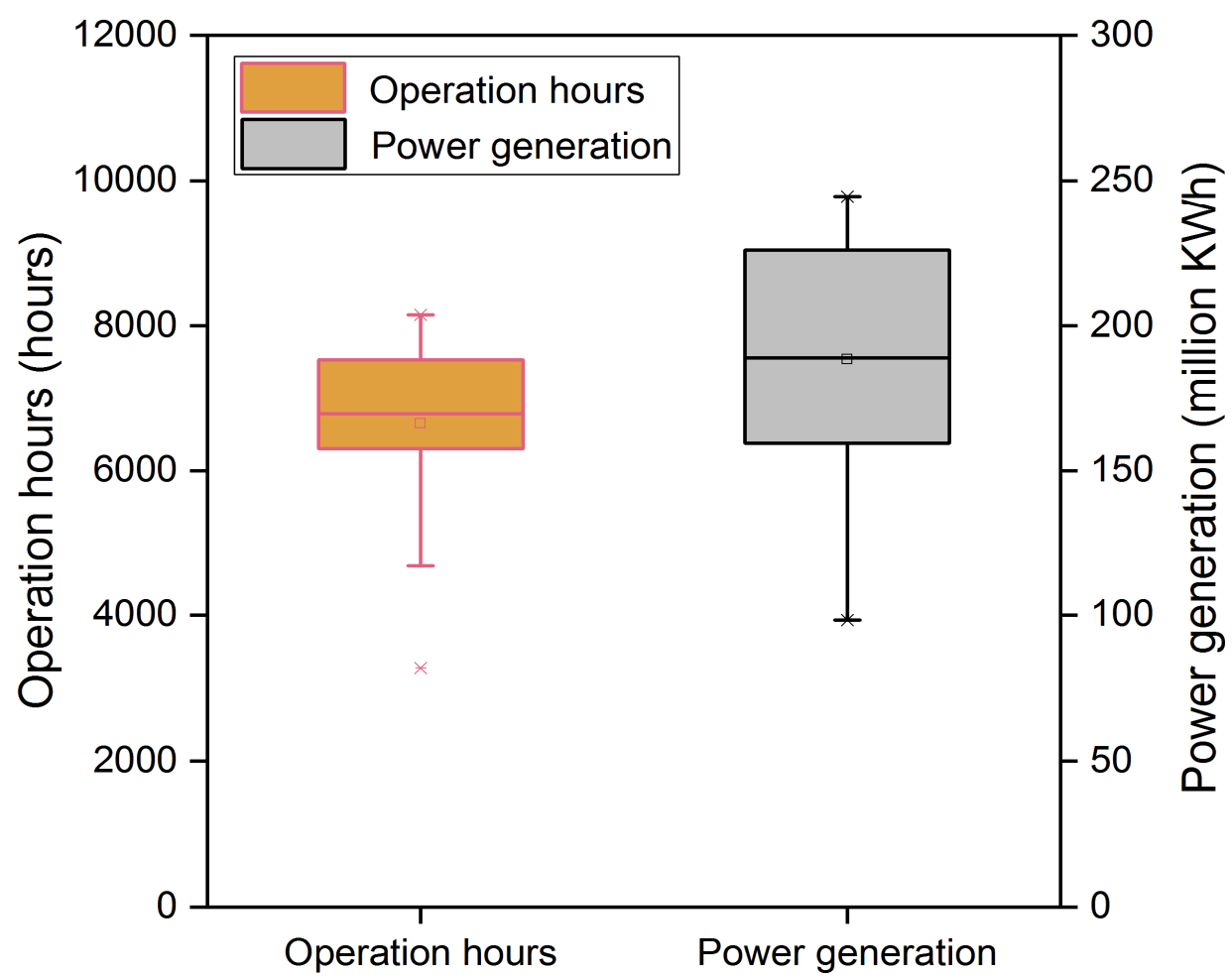

Figure 7. The annual operation hours and power generation of biomass based power plant in AHP, 2016.

Due to the relatively high investment and operating costs of biomass based power plants, various auxiliary policies such as financing policies, tax policies, mandatory grid connection and price support (feed-in tariff) have been proposed [32,44]. The "Renewable Energy Law" announced in 2005 and modified in 2009 indicated that favorable tariffs, development funds, and fiscal support were adopted for renewable energy development. The feed-in tariff set for agricultural and forestry residual power plants was $0.75 \mathrm{RMB} / \mathrm{KWh}$ from 2010, of which 0.35 and $0.40 \mathrm{RMB}$ was supported by government subsidies and national grids, respectively. However, the costs of fuel supplies still take a large share in the operational costs, with $60-70 \%$ of the total cost [30]. Zhang et al. [32] noted that most biomass power plants in China were operating at a loss even under the support of polices in 2012. Except for the national support funds, the first financial subsidies for straw utilization were issued by the Anhui government in 2014, i.e., 50, 40, $30 \mathrm{RMB} /$ tons for rice, wheat and other straw collections, respectively [45]. Under these subsidies, the number of straw collections was increased, resulting in the 17 out of 20 power plants making profits in 2016, based on the statistics from the Anhui Energy Bureau.

\subsection{GHG Emissions Mitigation Analysis}

Compared with fossil fuels such as coal, natural gas, and oil, a biomass power plant may effectively reduce greenhouse gas emissions and relieve the pressure of global climate change [46,47]. A study conducted by Sanchez et al. [20] estimated that the $\mathrm{CO}_{2}$ capture and sequestration potential of biomass for electricity is two times higher than that of biomass for cellulosic ethanol. The direct combustion of biomass for electricity generation is an appropriate approach for GHG mitigation, according to the investigation of Stefan Muench [48]. Based on the CM-092-V01 method of the Clean Development Mechanism (CDM) derived from the database of the United Nations Framework Convention on Climate Change (UNFCCC) and the Intergovernmental Panel on Climate Change (IPCC), the greenhouse gas emission reduction attributed to biomass power plants in AHP was calculated and is shown in Table 1 . The GHG mitigation attributed to biomass power plants in AHP ranged from 41,217 to 311,148 $\mathrm{t}$ $\mathrm{CO}_{2}$-eq, with a total yield of 3,436,490 $\mathrm{t} \mathrm{CO}_{2}$-eq in 2016. The different emissions reduction values are caused by equipment and depend on the scale of the plant, the raw material supply, the biomass 
utilization technology, target products and so on [49]. The reductions per unit production of a biomass power plant differ considerably aiming the power plants, ranging from 0.58 to 1.32 with a mean value of 0.75 , which is comparable to the data reported by Lin and He [43].

Table 1. Emission reductions of biomass power plants in 2016.

\begin{tabular}{|c|c|c|c|c|}
\hline Biomass Power Plant & $\begin{array}{l}\text { Installed Capacity } \\
\text { (MW) }\end{array}$ & $\begin{array}{l}\text { Annual Power } \\
\text { Supply (MWh) }\end{array}$ & $\begin{array}{l}\text { Emission Reductions } \\
\quad\left(\mathrm{t} \mathrm{CO} \mathrm{C}_{2} \text {-Eq) }\right.\end{array}$ & $\begin{array}{l}\text { Reduction Per Unit of } \\
\text { Production ( } t / M W h)\end{array}$ \\
\hline Anqin Datang & 30 & 184,200 & 149,540 & 0.81 \\
\hline Fuyang Guozhen & 24 & 176,060 & 232,115 & 1.32 \\
\hline Bengbu Kaidi & 24 & 153,160 & 125,216 & 0.82 \\
\hline Tongcheng Kaidi & 24 & 112,550 & 91,914 & 0.82 \\
\hline Wangjiang Kaidi & 24 & 158,140 & 126,343 & 0.80 \\
\hline Suzhou Huadian & 25 & 183,010 & 117,354 & 0.64 \\
\hline Guzhen National Energy & 30 & 220,910 & 141,973 & 0.64 \\
\hline Dangshan Guangda & 30 & 244,450 & 141,078 & 0.58 \\
\hline Nanling Kaidi & 30 & 203,980 & 137,606 & 0.67 \\
\hline Huoqiu Kaidi & 30 & 202,810 & 133,082 & 0.66 \\
\hline Huainan Kaidi & 30 & 131,050 & 88,324 & 0.67 \\
\hline Shouxian Guoneng & 30 & 230,970 & 147,971 & 0.64 \\
\hline Lujiang Kaidi & 30 & 187,910 & 125,121 & 0.67 \\
\hline Jinzhai Kaidi & 30 & 209,220 & 137,281 & 0.66 \\
\hline Huoshan Kaidi & 30 & 190,020 & 125,006 & 0.66 \\
\hline Hanshan Guangda & 30 & 237,290 & 311,148 & 1.31 \\
\hline Chizhou 325 & 25 & 160,540 & 98,131 & 0.61 \\
\hline Linquan National Energy & 30 & 243,210 & 154,907 & 0.64 \\
\hline Shucheng Zhongjieneng & 30 & 98,270 & 69,359 & 0.71 \\
\hline Mengcheng National Energy & 30 & 242,960 & 152,971 & 0.63 \\
\hline Langxi Li'ang & 30 & 148,360 & 146,837 & 0.99 \\
\hline Huaiyuan Guangda & 30 & 58,300 & 41,217 & 0.71 \\
\hline Dingyuan Guangda & 30 & 59,320 & 41,995 & 0.71 \\
\hline
\end{tabular}

\section{Conclusions}

The available amount of biomass including forest and agriculture residues reached 41.84 million tons in 2016. However, biomass resources with uneven distribution have a gradually decreasing trend from north to south. The distribution of the power plants is not consistent with the biomass potential, especially in the central and southern areas. The biomass density also indicated that these areas may not be suitable for biomass power plant development due to the higher operational cost for feedstock transport. However, the biomass power plants showed great potential for GHG emissions mitigation with a value of 3.44 million tons $\mathrm{CO}_{2}$-eq in 2016. However, further research, especially more quantitative synthetical analysis, should be conducted to quantify the impacts of straw-based biomass power plant in China.

Author Contributions: H.L. and X.M. conceived and designed this case-study as well as wrote the paper; M.D. and X.D. reviewed the paper; all authors interpreted the data. H.L. and X.M. authors contributed equally to this work as co-first authors.

Funding: This work was financially supported by the Youth development project from School of Resources and Environment AHAU, the Project Startup Foundation for Advanced Talents AHAU (No. YJ2018-56), The Natural Science Foundation of the Education Department of Anhui Province (NO. KJ2019A0207). The authors would like to thank the anonymous reviewers for their helpful comments, which improved the content of the present article.

Conflicts of Interest: The authors declare no conflict of interest. 


\section{Appendix A}

\section{Appendix A.1 Statistical Methods for Biomass Resources}

The amount of biomass resources in a region can directly determine whether the area is suitable for the development of biomass power generation. The crop straw and agro-forestry biomass resources were used as the main parts to calculate the biomass resources of the power industry in a region, and the two methods used to calculate these resources are as follows:

\section{Appendix A.1.1 Crop Straw Resources}

Crop straw, which refers to the stalk or stem of certain grains produced in the field, mainly includes rice straw, wheat straw, cotton straw, maize straw, bean straw and potato straw in AHP. The collectable amount of crop straw can be expressed as follows:

$$
\begin{gathered}
A_{y}=\left(\sum_{j} F_{j y} \times C R I_{j}\right) \times \eta_{j y} \\
\eta_{j y}=\left(R M_{j y} \times I M_{j}+R P_{j y} \times I P_{j}\right) \times\left(1-I_{\text {loss }}\right)
\end{gathered}
$$

where $A_{y}$ refers to the total collectable amount of straw in year $y, F_{j y}$ is the yield of crop $j$ in a year $y$, $C R I_{j}$ refers to the residue/grain ratio of crop $j$ (Table A1), $\eta_{j y}$ refers to the collection coefficient of crop $j$ in year $y, R M_{j y}$ is the mechanized harvesting ratio of crop $j$ in year $y, R P j y$ is the manual harvesting ratio of crop $j$ in year $y, I M j$ and $I P_{j}$ are the respective machinery and manpower harvesting straw coefficients of crop $j$, and $I_{\text {loss }}$ refers to the loss rate of straw in the harvest process, which was 0.05 in this study. Crop yield data in this paper were derived from the Statistics Bureau of AHP.

Table A1. Crop residue/grain ration and collect index in AHP.

\begin{tabular}{cccccc}
\hline & Rice & Wheat & Maize & Beans & Potato \\
\hline Residue/grain ration & 1.28 & 1.38 & 2.05 & 1.68 & 1.16 \\
Collection Index & 0.64 & 0.73 & 0.92 & 0.83 & 0.86
\end{tabular}

Note: Residue/grain ratio data were obtained from the "Comprehensive utilization planning of crop straw", issued by the National Development and Reform Commission Office and the Ministry of Agriculture.

\section{Appendix A.1.2 Forestry Byproducts}

Forestry byproduct resources refer to tree trunks, branches and leaves that remain from the process of harvesting and wood processing. This paper estimates the amount of forestry byproduct resources by taking the wood and bamboo harvesting quantity as the main parameter.

The calculation used to determine the amount of agro-forestry biomass resources in AHP is as follows:

where F: Amount of agroforestry biomass resources $\left(10^{4} \mathrm{t}\right)$

F11: Amount of residue from wood harvesting $\left(10^{4} \mathrm{t}\right)$

F12: Amount of residue from wood production and processing $\left(10^{4} t\right)$

F13: Amount of residue from bamboo harvesting $\left(10^{4} \mathrm{t}\right)$

F14: Amount of residue from bamboo production and processing

The details of the calculation method are as follows: 
Amount of Residue from Wood Harvesting

$$
\mathrm{F} 11=\mathrm{V} \times \mathrm{b} \times\left[\left(1-\mathrm{r}_{1}\right) / \mathrm{r}_{1}\right]
$$

Amount of Residue from Wood Production and Processing

$$
\mathrm{F} 12=\mathrm{V}_{1} \times \mathrm{pr} \times \mathrm{rr}
$$

Amount of Residue from Bamboo Harvesting

$$
\mathrm{F} 13=\mathrm{A} \times \mathrm{g} \times \mathrm{r}_{2}
$$

Amount of Residue from Bamboo Production and Processing

$$
\mathrm{F} 14=\mathrm{A} \times \mathrm{g} \times \mathrm{r}_{3}
$$

The amount of agroforestry biomass resources and associated parameters obtained from other studies are listed as follows:

\begin{tabular}{ccccc}
\hline & Full Name & Unit & Value & Sources \\
\hline $\mathrm{V}$ & Wood yield & $\begin{array}{c}10^{4} \\
\mathrm{~m}^{3}\end{array}$ & 561 & Anhui Statistical Yearbook \\
\hline $\mathrm{b}$ & $\begin{array}{c}\text { Average air-dry density of } \\
\text { the timber }\end{array}$ & $\mathrm{t} / \mathrm{m}^{3}$ & 0.618 & Wang et al., 2017 \\
\hline $\mathrm{r}_{1}$ & average wood outturn rate & $\%$ & 79.22 & Wang et al., 2017 \\
\hline $\mathrm{pr}$ & $\begin{array}{c}\text { Output ratio of production and } \\
\text { processing residues }\end{array}$ & $\%$ & 20 & Zhang et al., 2015 \\
\hline $\mathrm{rr}$ & $\begin{array}{c}\text { Recoverable ratio of production and } \\
\text { processing residues }\end{array}$ & $\%$ & 26.14 & Zhang et al., 2015 \\
\hline $\mathrm{A}$ & Bamboo Yield & $10^{4}$ & 16,031 & Anhui Statistical Yearbook \\
\hline $\mathrm{g}$ & Unit Quantity Bamboo Weight & $\mathrm{t}$ & 150 & Wang et al., 2017 \\
\hline $\mathrm{r}_{2}$ & $\begin{array}{c}\text { The proportion of bamboo leaf } \\
\text { weight equal to the bamboo weight }\end{array}$ & $\%$ & 38.07 & Wang et al., 2017 \\
\hline $\mathrm{r}_{3}$ & $\begin{array}{c}\text { The proportion of bamboo } \\
\text { processing residue }\end{array}$ & $\%$ & 62 & Wang et al., 2017 \\
\hline
\end{tabular}

Appendix A.2 The Calculation Method of GHG Emissions Reductions of Biomass Power Plants According to Clean Development Mechanism (CDM)

The greenhouse gas emission reduction of biomass power plant can be described by the following equation of CM-092-V01:

$$
\mathrm{ER}_{\mathrm{y}}=\mathrm{BE}_{\mathrm{y}}-\mathrm{PE}_{\mathrm{y}}-\mathrm{LE}_{\mathrm{y}}
$$

where $\mathrm{ER}_{\mathrm{y}}$ refers to the emissions reductions of the project activity during year $\mathrm{y}\left(\mathrm{tCO}_{2}\right), \mathrm{BE}_{\mathrm{y}}$ is defined as the base line emissions during year $\mathrm{y}\left(\mathrm{tCO}_{2}\right), \mathrm{PE}_{\mathrm{y}}$ is the project emissions during year $\mathrm{y}\left(\mathrm{tCO}_{2}\right)$, and $\mathrm{LE}_{\mathrm{y}}$ denotes the leakage emissions during year y $\left(\mathrm{tCO}_{2}\right)$. 
Appendix A.2.1 Baseline Emissions

$$
\mathrm{BE}_{\mathrm{y}}=\mathrm{BE} \mathrm{EL}, \mathrm{y}_{\mathrm{H}}+\mathrm{BE}_{\mathrm{BR}, \mathrm{y}}
$$

where $\mathrm{BE}_{\mathrm{y}}$ refers to the baseline emissions during year y $\left(\mathrm{tCO}_{2}\right) ; \mathrm{BE}_{\mathrm{EL}, \mathrm{y}}$ refers to the baseline emissions due to generation of electricity in year y $\left(\mathrm{tCO}_{2}\right) ; \mathrm{BE}_{\mathrm{BR}, \mathrm{y}}$ is the baseline emissions due to uncontrolled burning or decay of biomass residues in year $\mathrm{y}\left(\mathrm{tCO}_{2}\right)$.

Baseline Emissions from Electricity Generation

$$
\mathrm{BE}_{\mathrm{EL}, \mathrm{y}}=\mathrm{EG}_{\mathrm{PJ}, \mathrm{y}} \times \mathrm{EF}_{\mathrm{BL}, \mathrm{EL}, \mathrm{y}}
$$

where $\mathrm{BE}_{\mathrm{EL}, \mathrm{y}}$ refers to the baseline emissions due to generation of electricity in year $\mathrm{y}\left(\mathrm{t} \mathrm{CO}_{2}\right)$; $\mathrm{EG}_{\mathrm{PJ}, \mathrm{y}}$ is defined as the net quantity of electricity generated in the power plant in year $\mathrm{y}(\mathrm{MWh}) ; \mathrm{EF}_{\mathrm{BL}, \mathrm{EL}, \mathrm{y}}$ is the emission factor for electricity generation in the baseline in year y $\left(\mathrm{t} \mathrm{CO}_{2} / \mathrm{MWh}\right)$.

The Calculation of Uncontrolled Burning or Decay of Biomass Residues $\mathrm{BE}_{\mathrm{BR}, \mathrm{y}}$

$$
\mathrm{BE}_{\mathrm{BR}, \mathrm{y}}=\mathrm{BE}_{\mathrm{BR}, \mathrm{B} 1 / \mathrm{B} 3, \mathrm{y}}+\mathrm{BE}_{\mathrm{BR}, \mathrm{B} 2, \mathrm{y}}
$$

where $\mathrm{BE}_{\mathrm{BR}, \mathrm{y}}$ is the baseline emissions due to uncontrolled burning or decay of biomass residues in year $\mathrm{y}\left(\mathrm{tCO}_{2}\right) ; \mathrm{BE} \mathrm{BR}_{\mathrm{BR}} \mathrm{B} / \mathrm{B} 3$,y refers to the Baseline emissions due to aerobic decay or uncontrolled burning of biomass residues in year $\mathrm{y}\left(\mathrm{t}_{\mathrm{CO}}\right) ; \mathrm{BE}_{\mathrm{BR}, \mathrm{B} 2, \mathrm{y}}$ is the baseline emissions due to anaerobic decay of biomass residues in year y $\left(\mathrm{t} \mathrm{CO}_{2}\right)$.

Appendix A.2.2 Project Emission

$$
\mathrm{PE}_{\mathrm{y}}=\mathrm{PE}_{\mathrm{FF}, \mathrm{y}}+\mathrm{PE}_{\mathrm{EL}, \mathrm{y}}+\mathrm{PE}_{\mathrm{TR}, \mathrm{y}}+\mathrm{PE}_{\mathrm{BR}, \mathrm{y}}+\mathrm{PE}_{\mathrm{WW}, \mathrm{y}}
$$

where $\mathrm{PE}_{\mathrm{y}}$ is defined as the project emissions during year y $\left(\mathrm{tCO}_{2}\right) ; \mathrm{PE}_{\mathrm{FF}, \mathrm{y}}$ denotes the consumption $\left(\mathrm{t} \mathrm{CO}_{2}\right)$ is the emissions during the year y due to fossil fuel; $\mathrm{PE} \mathrm{EL}_{\mathrm{L}, \mathrm{y}}$ refers to the emissions during the year y due to electricity use off-site for the procession of biomass residues $\left(\mathrm{t} \mathrm{CO}_{2}\right) ; \mathrm{PE}_{\mathrm{TR}, \mathrm{y}}$ refers to the emissions during the year y due to transport of the biomass residues to the project plant $\left(\mathrm{tCO}_{2}\right) ; \mathrm{PE} B \mathrm{BR}, \mathrm{y}$ refers to the emissions from the combustion of biomass residues during the year $\mathrm{y}\left(\mathrm{tCO}_{2}\right) ; \mathrm{PE}_{\mathrm{WW}, \mathrm{y}}$ refers to the emissions from wastewater generated from the treatment of biomass residues in year $\mathrm{y}\left(\mathrm{t} \mathrm{CO}_{2}\right)$.

Appendix A.2.3 Leakage Emissions

$$
\mathrm{LE}_{\mathrm{y}}=\mathrm{EF}_{\mathrm{CO} 2, \mathrm{LE}} \times \sum_{\mathrm{n}} \mathrm{BR}_{\mathrm{PJ}, \mathrm{n}, \mathrm{y}} \times \mathrm{NCV}_{\mathrm{n}, \mathrm{y}}
$$

where $\mathrm{LE}_{\mathrm{y}}$ is defined as the leakage emissions during year $\mathrm{y}(\mathrm{tCO}), \mathrm{EF}_{\mathrm{CO}}, \mathrm{LE}$ refers to the $\mathrm{CO}_{2}$ emission factor for fossil fuels with the highest carbon content in China $\left(\mathrm{tCO}_{2} / \mathrm{GJ}\right) ; \mathrm{BR}_{\mathrm{PJ}, \mathrm{n}, \mathrm{y}}$ is the amount of biomass waste of category $\mathrm{n}$ used by the project plant within the project boundary in year $\mathrm{y}(\mathrm{GJ} / \mathrm{dry}$ basis $t)$; $N C V_{n, y}$ is the net calorific value of biomass waste of category $n$ in year $y(G J /$ dry basis $t)$.

\section{References}

1. IEA. Global Energy \& CO2 Status Report 2017; IEA: Paris, France, 2018; p. 1.

2. Tong, D.; Zhang, Q.; Davis, S.J.; Liu, F.; Zheng, B.; Geng, G.; Xue, T.; Li, M.; Hong, C.; Lu, Z.; et al. Targeted emission reductions from global super-polluting power plant units. Nat. Sustain. 2018, 1, 59-68. [CrossRef] 
3. Tao, S.; Ru, M.Y.; Du, W.; Zhu, X.; Zhong, Q.R.; Li, B.G.; Shen, G.F.; Pan, X.L.; Meng, W.J.; Chen, Y.L.; et al. Quantifying the rural residential energy transition in China from 1992 to 2012 through a representative national survey. Nat. Energy 2018, 3, 567-573. [CrossRef]

4. Wang, L.; Dai, J. The perspectives on the long-term trend of China's energy development. Int. Pet. Econ. 2017, 8, 58-61, (In Chinese with English abstract).

5. Chu, S.; Cui, Y.; Liu, N. The path towards sustainable energy. Nat. Mater. 2017, 16, 16-22. [CrossRef] [PubMed]

6. Chikkatur, A.P.; Chaudhary, A.; Sagar, A.D. Coal Power Impacts, Technology, and Policy: Connecting the Dots. Annu. Rev. Environ. Resour. 2011, 36, 101-138. [CrossRef]

7. Li, H.; Liu, G.; Cao, Y. Levels and environmental impact of PAHs and trace element in fly ash from a miscellaneous solid waste by rotary kiln incinerator, China. Nat. Hazards 2015, 9, 811-822. [CrossRef]

8. Li, H.; Liu, G.; Cao, Y. Content and Distribution of Trace Elements and Polycyclic Aromatic Hydrocarbons in Fly Ash from a Coal-Fired CHP Plant. Aerosol Air Qual. Res. 2014, 14, 1179-1188. [CrossRef]

9. Li, H.; Chen, Y.; Cao, Y.; Liu, G.; Li, B. Comparative study on the characteristics of ball-milled coal fly ash. J. Therm. Anal. Calorim. 2016, 124, 839-846. [CrossRef]

10. Greenblatt, J.B.; Brown, N.R.; Slaybaugh, R.; Wilks, T.; Stewart, E.; McCoy, S.T. The Future of Low-Carbon Electricity. Annu. Rev. Environ. Resour. 2017, 42, 289-316. [CrossRef]

11. Zhou, X.; Wang, F.; Hu, H.; Yang, L.; Guo, P.; Xiao, B. Assessment of sustainable biomass resource for energy use in China. Biomass Bioenergy 2011, 35, 1-11. [CrossRef]

12. Bentsen, N.S.; Felby, C. Biomass for energy in the European Union-A review of bioenergy resource assessments. Biotechnol. Biofuels 2012, 5, 25. [CrossRef] [PubMed]

13. Liu, W.; Spaargaren, G.; Heerink, N.; Mol, A.P.J.; Wang, C. Energy consumption practices of rural households in north China: Basic characteristics and potential for low carbon development. Energy Policy 2013, 55, 128-138. [CrossRef]

14. Panwar, N.L.; Kaushik, S.C.; Kothari, S. Role of renewable energy sources in environmental protection: A review. Renew. Sustain. Energy Rev. 2011, 15, 1513-1524. [CrossRef]

15. Robertson, G.P.; Hamilton, S.K.; Barham, B.L.; Dale, B.E.; Izaurralde, R.C.; Jackson, R.D.; Landis, D.A.; Swinton, S.M.; Thelen, K.D.; Tiedje, J.M. Cellulosic biofuel contributions to a sustainable energy future: Choices and outcomes. Science 2017, 356, eaal2324. [CrossRef] [PubMed]

16. Zhao, G. Assessment of potential biomass energy production in China towards 2030 and 2050. Int. J. Sustain. Energy 2018, 37, 47-66. [CrossRef]

17. McKendry, P. Energy production from biomass (part 2): Conversion technologies. Bioresour. Technol. 2002, 83, 47-54. [CrossRef]

18. Wu, C.; Yin, X.; Yuan, Z.; Zhou, Z.; Zhuang, X. The development of bioenergy technology in China. Energy 2010, 35, 4445-4450. [CrossRef]

19. Wang, H.W.; Shi, Y.J.; Hong-Li, L.I.; Zhao, B.G.; Zhu, C. Analysis on Energy-Saving Emissions Effect of Biomass Power Generation. Power Syst. Technol. 2007, 31, 344-346.

20. Sanchez, D.L.; Nelson, J.H.; Johnston, J.; Mileva, A.; Kammen, D.M. Biomass enables the transition to a carbon-negative power system across western North America. Nat. Clim. Chang. 2015, 5, 230-235. [CrossRef]

21. Rosillo-Calle, F.; Woods, J. The Biomass Assessment Handbook: Energy for a Sustainable Environment; Routledge: New York, NY, USA, 2015; p. 7.

22. Zheng, H.; Xing, X.; Hu, T.; Zhang, Y.; Zhang, J.; Zhu, G.; Li, Y.; Qi, S. Biomass burning contributed most to the human cancer risk exposed to the soil-bound PAHs from Chengdu Economic Region, western China. Ecotoxicol. Environ. Saf. 2018, 159, 63-70. [CrossRef]

23. Liu, J.; Wang, S.; Wei, Q.; Yan, S. Present situation, problems and solutions of China's biomass power generation industry. Energy Policy 2014, 70, 144-151. [CrossRef]

24. Fournel, S.; Palacios, J.H.; Morissette, R.; Villeneuve, J.; Godbout, S.; Heitz, M.; Savoie, P. Influence of biomass properties on technical and environmental performance of a multi-fuel boiler during on-farm combustion of energy crops. Appl. Energy 2015, 141, 247-259. [CrossRef]

25. Hao, L.; Hao, D.; Zhou, D.Q.; Peng, Z. A site selection model for a straw-based power generation plant with $\mathrm{CO}_{2}$ emissions. Sustainability 2014, 6, 7466-7481. 
26. Jumpponen, M.; Rönkkömäki, H.; Pasanen, P.; Laitinen, J. Occupational exposure to solid chemical agents in biomass-fired power plants and associated health effects. Chemosphere 2014, 104, 25-31. [CrossRef] [PubMed]

27. Freiberg, A.; Scharfe, J.; Murta, V.C.; Seidler, A. The Use of Biomass for Electricity Generation: A Scoping Review of Health Effects on Humans in Residential and Occupational Settings. Int. J. Environ. Res. Public Health 2018, 15, 354. [CrossRef] [PubMed]

28. Zhao, X.G.; Li, A. A multi-objective sustainable location model for biomass power plants: Case of China. Energy 2016, 112, 1184-1193. [CrossRef]

29. Juntarawijit, C.; Juntarawijit, Y.; Boonying, V. Health impact assessment of a biomass power plant using local perceptions: Cases studies from Thailand. Impact Assess. Proj. Apprais. 2014, 32, 170-174. [CrossRef]

30. Zhang, Q.; Zhou, D.; Zhou, P.; Ding, H. Cost Analysis of straw-based power generation in Jiangsu Province, China. Appl. Energy 2013, 102, 785-793. [CrossRef]

31. Nguyen, T.L.T.; Hermansen, J.E.; Mogensen, L. Environmental performance of crop residues as an energy source for electricity production: The case of wheat straw in Denmark. Appl. Energy 2013, 104, 633-641. [CrossRef]

32. Zhang, Q.; Zhou, D.; Fang, X. Analysis on the policies of biomass power generation in China. Renew. Sustain. Energy Rev. 2014, 32, 926-935. [CrossRef]

33. Xingang, Z.; Zhongfu, T.; Pingkuo, L. Development goal of 30GW for China's biomass power generation: Will it be achieved? Renew. Sustain. Energy Rev. 2013, 25, 310-317. [CrossRef]

34. Yang, Q.; Fei, H.; Chen, Y.Q.; Yang, H.P.; Chen, H.P. Greenhouse gas emissions of a biomass-based pyrolysis plant in China. Renew. Sustain. Energy Rev. 2016, 53, 1580-1590. [CrossRef]

35. Wu, H.; Yuan, Z.; Zhang, Y.; Gao, L.; Liu, S. Life-cycle phosphorus use efficiency of the farming system in Anhui Province, Central China. Resour. Conserv. Recycl. 2014, 83, 1-14. [CrossRef]

36. Li, H.; Cao, Y.; Wang, X.; Ge, X.; Li, B.; Jin, C. Evaluation on the Production of Food Crop Straw in China from 2006 to 2014. BioEnergy Res. 2017, 10, 949-957. [CrossRef]

37. Krukanont, P.; Prasertsan, S. Geographical distribution of biomass and potential sites of rubber wood fired power plants in Southern Thailand. Biomass Bioenergy 2004, 26, 47-59. [CrossRef]

38. Wang, X.W.; Cai, Y.P.; Chao, D. Evaluating China's biomass power production investment based on a policy benefit real options model. Energy 2014, 73, 751-761. [CrossRef]

39. Ding, C. Industrial Boiler Equipment; China Machine Press: Beijing, China, 2005.

40. Rodríguez-Monroy, C.; Mármol-Acitores, G.; Nilsson-Cifuentes, G. Electricity generation in Chile using non-conventional renewable energy sources-A focus on biomass. Renew. Sustain. Energy Rev. 2018, 81, 937-945. [CrossRef]

41. Suramaythangkoor, T.; Gheewala, S.H. Potential of practical implementation of rice straw-based power generation in Thailand. Energy Policy 2008, 36, 3193-3197. [CrossRef]

42. Sun, Y.; Cai, W.; Chen, B.; Guo, X.; Hu, J.; Jiao, Y. Economic analysis of fuel collection, storage, and transportation in straw power generation in China. Energy 2017, 132, 194-203. [CrossRef]

43. Lin, B.; He, J. Is biomass power a good choice for governments in China? Renew. Sustain. Energy Rev. 2017, 73, 1218-1230. [CrossRef]

44. Wang, T.; Huang, H.; Yu, C.; Fang, K.; Zheng, M.; Luo, Z. Understanding cost reduction of China's biomass direct combustion power generation-A study based on learning curve model. J. Clean. Prod. 2018, 188, 546-555. [CrossRef]

45. Opinions on the Implementation of Financial Awards for Crop Residue Electricity Generation. Available online: http://ah.anhuinews.com/system/2014/07/17/006489341.shtml (accessed on 7 September 2019).

46. Yao, H. Potential to Decrease GHG Emissions from Biomass Resources in China. Master's Thesis, Lappeenranta University of Technology, Lappeenranta, Finland, 2016.

47. Wang, X.; Sun, C.; Long, Z.; Peng, L.; Zeng, M. Research on the Emission Reduction Problem of Biomass Power Generation. In Proceedings of the International Conference on Computer Engineering, Information Science \& Application Technology, Guilin, China, 24-25 September 2016. 
48. Muench, S. Greenhouse gas mitigation potential of electricity from biomass. J. Clean. Prod. 2015, 103, $483-490$. [CrossRef]

49. Sebastián, F.; Royo, J.; Gómez, M.; Duic', N.; Guzovic, Z. Cofiring versus biomass-fired power plants: GHG (Greenhouse Gases) emissions savings comparison by means of LCA (Life Cycle Assessment) methodology. Energy 2011, 36, 2029-2037. [CrossRef] 